Yasin Türker, Mustafa Kayan'1, Mehmet Munduz'1, Selçuk Yaşar', Mehmet Özaydın²

Department of Cardiology, Faculty of Medicine, Düzce University, Düzce,

${ }^{1}$ From Departments of Radiology, and ${ }^{2}$ Cardiology, Faculty of Medicine, Süleyman Demirel University, Isparta-Turkey

Address for Correspondence/Yazışma Adresi: Dr. Yasin Türker Department of Cardiology, Faculty of Medicine, Duzce University, Düzce-Turkey Phone: +90 3805421390 Fax: +90 3805421387

E-mail: dryasinturker@hotmail.com

Available Online Date / Çevrimiçi Yayın Tarihi: 18.05.2011

(c) Telif Hakkı 2011 AVES Yayıncıllk Ltd. Sti. - Makale metnine www.anakarder.com web sayfasından ulaşılabilir.

(C) Copyright 2011 by AVES Yayıncllk Ltd. - Available on-line at www.anakarder.com doi:10.5152/akd.2011.098

\section{Atrial angiosarcoma imaged by F-18 FDG PET/CT}

\section{F-18 FDG PET/CT ile görüntülenen atriyal anjiyosarkom}

Sarcomas arising primarily in the heart are rare. Angiosarcoma is an extremely rare, most common primary cardiac malignant tumour. We report the F-18 fluorodeoxyglucose positron emission tomography (F-18 FDG PET) / computed tomography (CT) images of a patient with an invasive angiosarcoma arising from the right atrium. A 55 -year-old woman with primary high-grade cardiac angiosarcoma underwent tumour resection at another centre was referred to our institution for postoperative F-18 FDG PET/ CT scans to assess the residual/metastatic disease. Preoperative magnetic resonance imaging revealed a $6.5 \times 3.5-\mathrm{cm}$ mass extending along the lateral wall of the right atrium surrounding the inferior vena cava and atria ventricular junction, extending to aortic root as well as into the right pericardium. Concomitant pericardial effusion was noticed. The debulking surgery was performed to remove the mass. Four weeks after surgery, the patient underwent the F-18 FDG $\mathrm{PET} / \mathrm{CT}$ scans (1hour after the administration of $465 \mathrm{MBq}$ F-18 FDG with the subject fasted for $6 \mathrm{~h}$ beforehand). Three-plane images (PET, contrast-enhanced CT and fused PET/CT in axial, sagittal and coronal projections) revealed a residual mass with significantly increased uptake of F-18 FDG (SUVmax of 16.4) in the right atrium measuring $5.0 \times 4.5 \mathrm{~cm}$ in size (Fig. 1, Video 1, 2. See corresponding video/movie images at www.anakarder.com ). There was no evidence of distant metastatic disease. The patient subsequently underwent chemotherapy regimen.

Still, primary cardiac sarcoma is a rare clinical entity, with an incidence of $0.0001 \%$ in collected autopsy series. The majority of patients with cardiac sarcomas presents with unresectable tumours and have a poor prognosis. Prognosis of primary cardiac angiosarcoma is generally poor with usually a short and fatal course: the mean survival for patients with primary cardiac angiosarcoma is $9-12$ months following diagnosis. Treatment options for these sarcomas include surgery, chemotherapy, and radiation therapy, alone or in combination. Complete resection of cardiac sarcoma is difficult, in view of the location and extent of involvement. PET with F-18 FDG, an analogue of glucose, provides valuable functional information based on the increased glucose uptake and glycolysis of cancer cells and depicts metabolic abnormalities. F-18 FDG PET/CT acquires PET and CT data in the same imaging



Figure 1. PET (top), contrast-enhanced CT (middle) and fused PET/CT (bottom) images in axial, sagittal and coronal projections of a residual mass in the right atrium

CT - computed tomography, PET - pozitron emission tomography

session and allows accurate anatomical localization of the lesions detected on the PET/CT scan.

İlknur Ak, Öznur Dilek Çiftçi, Zeki Üstünel1', Muammer Cumhur Sivrikoz*

From Departments of Nuclear Medicine and *Thoracic Surgery, Faculty of Medicine, Eskişehir Osmangazi University, Eskişehir

${ }^{1}$ Clinic of Oncology, Eskişehir Ümit Hospital, Eskişehir-Turkey

Address for Correspondence/Yazışma Adresi: Dr. İlknur Ak

Department of Nuclear Medicine, Faculty of Medicine, Osmangazi University 26480 Eskişehir-Turkey

Phone: +90 2222392979 Fax: +90 2222291150

E-mail: ilknur_ak@yahoo.com

Available Online Date / Cevrimiçi Yayın Tarihi: 18.05.2011

(C) Telif Hakkı 2011 AVES Yayıncllk Ltd. Şti. - Makale metnine www.anakarder.com web sayfasindan ulaşlabilit.

(C) Copyright 2011 by AVES Yayıncillk Ltd. - Available on-line at www.anakarder.com doi:10.5152/akd.2011.099

\section{Naxos-Carvajal disease: a rare cause of cardiomyopathy with woolly hair and palmoplantar hyperkeratosis}

\section{Naxos-Carvajal hastalığı: Palmoplantar keratozis ve yünsü saç ile karakterli nadir bir kardiyomiyopati nedeni}

Naxos-Carvajal disease is a rare autosomal recessive inherited disease characterized by a triad of ventricular dysplasia/dilated cardiomyopathy, woolly hair and palmoplantar hyperkeratosis. The pathological process is characterized by progressive loss of myocardial fibrils 